\title{
IDENTIFIKASI DAN ANALISA KARAKTERISTIK KETERDAPATAN SINK HOLE DI AREA PAKET PEMBANGUNAN JALAN BARU JERUKWUDEL-BARAN-DUWET, GUNUNG KIDUL, DIY
}

\author{
IDENTIFICATION AND ANALYSIS OF THE SINK HOLES CHARACTERISTIC IN THE AREA OF \\ THE NEW ROAD CONSTRUCTION PROJECT, JERUKWUDEL-BARAN-DUWET, GUNUNG KIDUL, \\ DIY
}

\author{
Aloysius Andrianto Saputro ${ }^{1 *}$, Christanto Yudha Saputra Sukamta ${ }^{2}$, Herlina Sulistyani ${ }^{3}$ \\ ${ }^{1}$ Ahli Pertama Teknik Jalan dan Jembatan, Kementerian PUPR \\ ${ }^{2,3}$ Ahli Muda Teknik Jalan dan Jembatan, Kementerian PUPR \\ Korespondensi: aloysius.saputro@pu.go.id
}

\begin{abstract}
ABSTRAK
Pembangunan jalan baru yang melintasi desa Jerukwudel-Baran-Duwet, merupakan salah satu paket pembangunan yang bertujuan untuk pengembangan infrastruktur jalan di wilayah Pantai Selatan Jawa. Pembangunan jalan ini berada di wilayah Kabupaten Gunung Kidul yang termasuk dalam morfologi pegunungan karst, hal tersebut menyebabkan banyak ditemukan sink hole yang dapat memicu terjadinya amblesan tanah (luweng) dan membahayakan bangunan/konstruksi diatas ataupun sekitarnya. Metode penelitian yang dilakukan oleh penulis adalah pengambilan data lapangan yang ditunjang oleh data geolistrik. Didapatkan 26 sink hole yang terbagi menjadi 2 jenis yaitu collapse sink hole (18 titik) berada di tebing jalan dan memiliki diameter rata-rata 1.1 meter. Kemudian drop out sink hole (8 titik) berada di badan jalan, dan memiliki diameter rata-rata 0.9 meter. Litologi dominan adalah batuan karbonat (packestone, wackestone dan batugamping kristalin). Secara geomorfologi, terdapat dua bentukan yaitu doline dan cone karst, kedua bentukan tersebut berasosiasi dengan jenis sink hole yang terbentuk. Dimana pada doline ditemukan dropout sink hole dan pada cone karst ditemukan collapse sink hole. Dari interpretasi geolistrik, dapat ditentukan juga adanya potensi rongga bawah permukaan dan amblesan tanah yang sudah terbentuk di permukaan.
\end{abstract}

\section{Kata kunci: Gunung Kidul, Karst, Sink hole}

\begin{abstract}
The construction of a new road that crosses the village of Jerukwudel-Baran-Duwet, is one of the development projects aimed at the development of road infrastructure in the South Coast region of Java. The construction of this road is in the area of Gunung Kidul Regency which is has a karst morphology, it causes the formation of sink holes that can trigger the occurrence of soil sinking (luweng) and endanger buildings / construction above or surrounding areas. The research method conducted by the author is the retrieval of field data supported by geoelectric data. From the field, obtained 26 sink holes that are divided into 2 types, collapse sink hole (18 locatiosn) is on the cliff and has an average diameter of 1.1 meters. Then the drop out sink hole (8 locations) is on the body of the road, and has an average diameter of 0.9 meters. The dominant lithology is carbonate rocks (packestone, wackestone and crystalline rock). There are two morphology forms in this area, doline and cone
\end{abstract}


karst, both forms are associated with the type of sink hole formed. Where on the doline found dropout sink hole and in cone karst found collapse sink hole. From the interpretation of geoelectric data, it can also be determined the potential of subsurface cavities and soil sinks that have formed on the surface.

\section{Keywords: Gunung Kidul, Karst, Sink hole}

\section{PENDAHULUAN}

Pembangunan jalan baru wilayah Pantai Selatan Jawa (JJLS) diharapkan dapat mengurangi beban lalu lintas di lintas Pantai Utara Jawa sekaligus menumbuhkan dan meningkatkan perekonomian baru di bagian selatan. Jalan baru ini sendiri melewati sebagian besar wilayah Gunung Kidul, yang secara geomorfologi merupakan kawasan pegunungan karst dengan batuan penyusun utamanya berupa batuan karbonat. Pembangunan Jalan Baru Jerukwudel-Baran-Duwet ini (Gambar 1) menghubungkan Desa Jerukwudel Kecamatan Girisubo di sisi selatan ke Desa Duwet Kecamatan Rongkop di sisi utara Kabupaten Gunung Kidul. Jalur baru ini melintasi 5 Desa di dua Kecamatan tersebut, yaitu Desa Tileng, Desa Jerukwudel, Desa Nglindur, Desa Karangweni dan Desa Semugih. Pada paket pembangunan jalan tersebut, sering ditemukan fenomena geologi berupa sink hole. Fenomena sink hole tersebut merupakan permasalahan yang timbul karena pembangunan jalan berada di wilayah karst, dimana amblesan tanah tersebut dapat mempengaruhi faktor keselamatan jalan (dapat menyebabkan amblesan jalan dan longsor di kemudian hari) dan dibutuhkan penanganan khusus untuk dapat mengatasinya. Hal tersebut menyebabkan perlu adanya identifikasi dan analisa khusus terkait keterdapatan sink hole tersebut, agar dapat menjadi acuan kedepannya untuk tindakan preventif maupun mitigasi bencana.

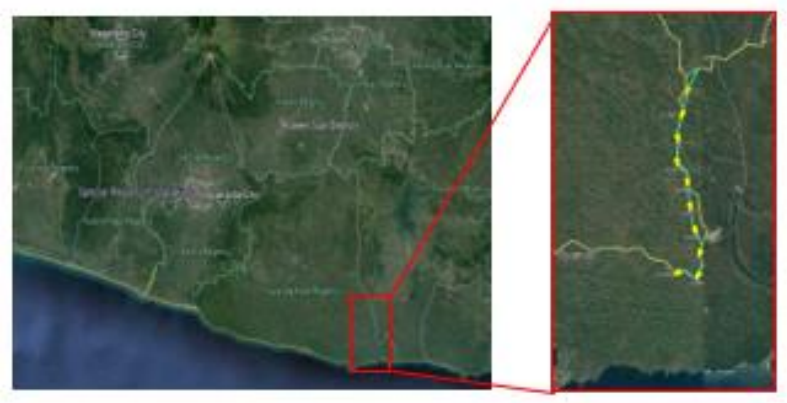

Gambar 1. Lokasi Paket pembangunan Jalan baru Jerukwudel-Baran-Duwet Sumber: Google Earth

\section{TINJAUAN PUSTAKA}

Fisiografi daerah penelitian menurut Van Bemmelen (1949), termasuk ke dalam zona fisiografi Pegunungan Selatan. Dimana daerah penelitian termasuk dalam satuan dataran tinggi karst meliputi daerah Gading, Wonosari, Playen, hingga Semanu. Pegunungan Karst sendiri merupakan sebuah morfologi/bentang alam yang terbentuk karena adanya pelarutan oleh air (Air permukaan/air hujan maupun air bawah permukaan/sungai) baik pada permukaan batuan atas maupun pada batuan bawah permukaan, sehingga terbentuk bentang alam berupa bukit (bagian resisten pelarutan) dan lembah (bagian yang mengalami pelarutan) (Hugget, 2007). Kemudian secara geologi, lokasi paket berada di Formasi Batuan Oyo-Wonosari (TMWL). Formasi ini terdiri terutama dari batugamping dan napal. Penyebarannya meluas hampir setengah bagian selatan dari Pegunungan Selatan memanjang ke arah timur, membelok ke arah utara di sebelah timur perbukitan Panggung hingga mencapai bagian barat dari daerah depresi Wonogiri-Baturetno. (Rahardjo dkk, 1977 dalam Toha dkk,1994). Kedua hal tersebut dapat memicu munculnya fenomena geologi berupa sink hole, sink hole sendiri merupakan sebuah terminologi untuk lubang terbuka di area karst/batuan karbonat dimana terdapat aliran air yang masuk ke dalamnya, terbentuk karena adanya air yang meresap kedalam batuan karbonat di area morfologi depresi/lembah, kemudian air tersebut melarutkan batuan karbonat, sehingga terbentuklah rongga dalam batuan. Proses pembentukan Sink hole dapat dibagi menjadi enam genesa menurut Waltham, dkk. (2005), yaitu; solution sink hole, collapse sink hole, dropout sink hole, buried sink hole, caprock sink hole, dan suffosion sink hole (Gambar 2). Solution sink hole dan collapse sink hole merupakan jenis sink hole yang terjadi lansung pada batuan karbonat yang tidak memiliki batuan penutup diatasnya. Sink hole jenis ini banyak ditemukan pada bedrock batuan gamping/dolomit/gipsum yang tersingkap di permukaan, dengan ciri-ciri turunnya permukaan batuan (terkadang membentuk doline) pada area rongga/celah/gua bawah permukaan (Untuk 
Solution sink hole) dan terbentuknya runtuhan/longsoran batuan pada area diatas rongga/celah/gua bawah permukaan (Untuk collapse sink hole). Sedangkan Caprock sink hole, Dropout sink hole, Suffosion sink hole, dan Buried sink hole merupakan jenis-jenis sink hole yang terjadi pada daerah batuan karbonat dengan batuan penutup/caprock diatasnya (Batuan sedimen lain ataupun lapisan tanah). Genesa pembentukan ke empat sink hole diatas berkaitan erat dengan jenis lapisan penutup dan proses pengisian celah atau rongga oleh litologi penutup tersebut. jika lapisan penutup merupakan endapan atau tanah yang kohesif seperti lempung, maka amblesan yang terjadi kemungkinan bertipe dropout sink hole, sedangkan jika lapisan penutup tersusun atas endapan pasiran, maka amblesan yang terjadi bertipe suffosion sink hole. Namun jika litologi yang mengalami amblesan merupakan lapisan batuan lain maka proses pembentukan sink hole disebut caprock sink hole. Buried sink hole terjadi lebih karena adanya proses pembebanan dan kompaksi yang dialami oleh endapan penutup secara perlahan dan waktu yang lama (Waltham, dkk, 2005).

\section{METODE PENELITIAN}

Metode penelitian yang dilakukan oleh penulis adalah pengambilan data lapangan (Data permukaan) yang kemudian diperkuat dengan data sekunder, data geolistrik (Data bawah permukaan). Pengambilan data lapangan dilakukan di sepanjang rencana pembangunan jalan baru JerukwudelBaran-Duwet sepanjang \pm 10 kilometer. Pembangunan jalan baru sendiri sudah selesai sekitar $80 \%$, sehingga pengambilan data lapangan dilakukan dengan 2 metode. Untuk data sink hole di bagian badan jalan yang sudah ditimbun, penulis meminta data kepada kontraktor pekerjaan di lapangan. Sedangkan untuk data sink hole di area tebing pinggir jalan dan sisa $20 \%$ jalan yang belum dibangun, penulis melakukan pengambilan data lapangan secara langsung. Data lapangan yang diambil berupa pengamatan, pemerian, dan pengukuran secara langsung baik kondisi geologi, morfologi, maupun deskripsi sink hole. Data geologi yang didapatkan berupa deskripsi litologi di sekitar area sink hole, kemudian data geomorfologi yang didapatkan merupakan jenis morfologi di sekitar area sink hole, dan yang terakhir deskripsi sink hole meliputi koordinat letak, ukuran ataupun diameter, karakteristik, jenis, dan dokumentasi sink hole. Kemudian dari data-data yang didapatkan tersebut, dapat dibuat database dan peta persebaran sink hole di lokasi paket pembangunan Jalan Baru Jerukwudel-Baran-Duwet.

Data geofisika berupa geolistrik didapatkan dari pengukuran yang dilakukan oleh tim survey awal PPK 1.2 DIY. Data yang diambil dilakukan pada 7 lintasan dengan jarak antar elektroda yang digunakan sebesar 10 meter, dan memiliki panjang lintasn 320 meter di sekitar paket pembangunan Jalan Baru Jerukwudel-Baran-Duwet. Pengukuran dilakukan di lokasi yang mempunyai lapisan batuan keras pada dasar jalan sehingga dapat diketahui kemenerusan dari batuan. Pengukuran geolistrik atau tahanan jenis di daerah paket pembangunan Jalan Baru Jerukwudel-Baran-Duwet menggunakan metode pengukuran geolistrik berupa tahanan jenis 2D konfigurasi Wenner Schlumberger. Metode ini dipilih karena mampu memberikan informasi bawah permukaan secara vertikal maupun horisontal. Secara umum metode ini dilakukan dengan pemasangan elektroda di sepanjang lintasan dan pengukuran tahanan jenis sepanjang lintasan. Adapun tahapan pengambilan data ini antara lain: 1 . Penentuan titik pengukuran di lapangan dan penentuan arah lintasan; 2. Penempatan titik pengukuran; 3. Pengambilan data geolistrik; 4. Pengolahan data geolistrik; 5. Pengoperasian program RES2DINV 
Identifikasi.., Aloysius Andrianto Saputro ${ }^{(1)}$, Christanto Yudha Saputra Sukamta ${ }^{(2)}$, Herlina Sulistyani ${ }^{(3)}$

Table 2.1. The six types of sinkholes, with typical cross sections and major parameters for each type; the dropout and suffosion sinkholes may be described as forms of subsidence sinkholes.

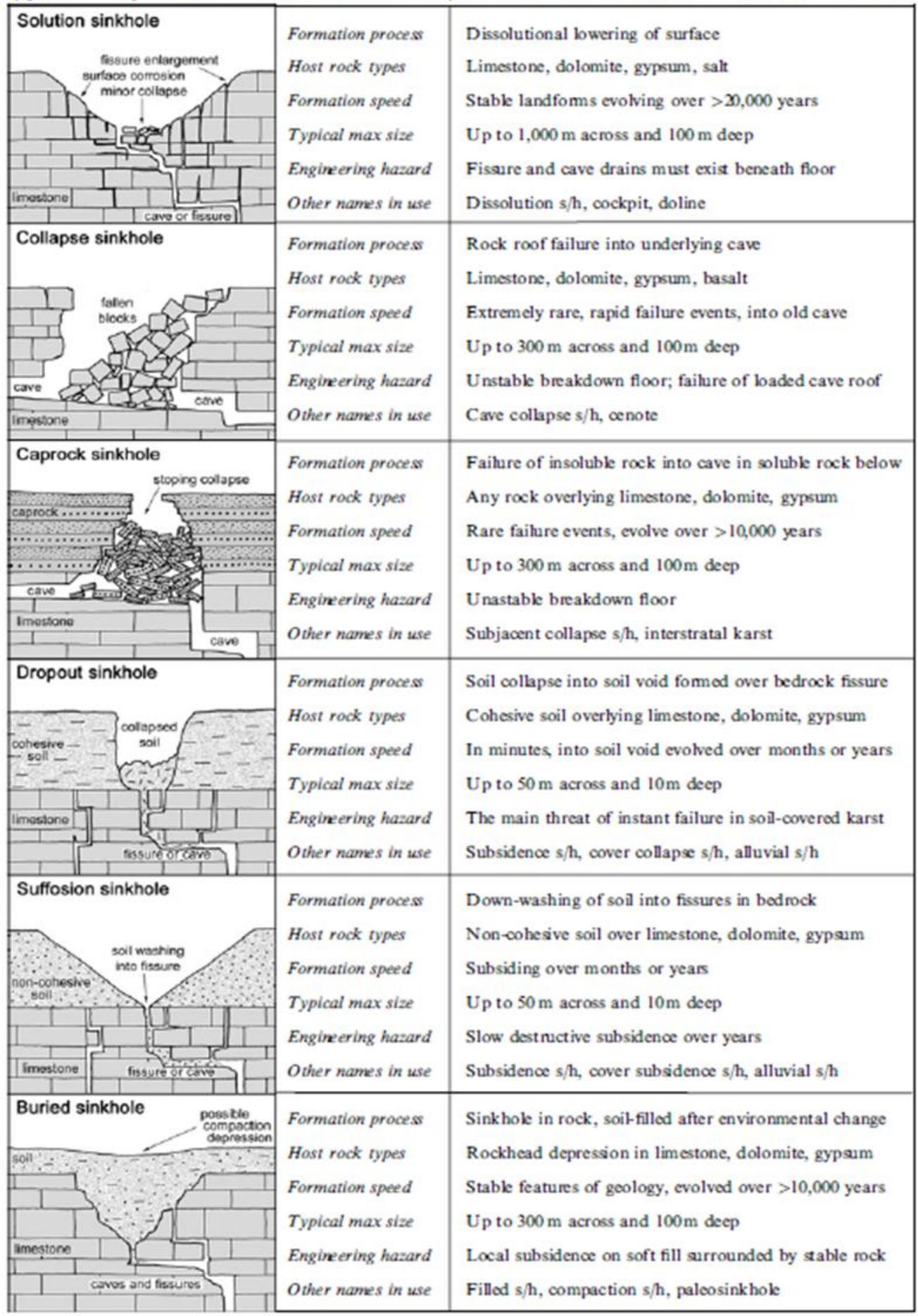

Gambar 2. Jenis-jenis Sink hole menurut genesa pembentukannya

(Sumber: Waltham, dkk, 2005) 


\section{HASIL DAN PEMBAHASAN}

\section{Hasil dan Interpretasi Data Lapangan}

Dari hasil pengambilan data lapangan, didapatkan identifikasi sink hole sebanyak 26 sink hole sepanjang trase pembangunan jalan baru Jerukwudel-Baran-Duwet (Gambar 3). Sink hole tersebut terbagi menjadi 2 jenis. Jenis sink hole pertama yaitu collapse sink hole, ditemukan sebanyak 18 titik dan semuanya berada di area tebing pinggir trase jalan. Tebing tersebut beberapa merupakan tebing alami dan beberapa merupakan tebing hasil penggalian pembangunan jalan. Sink hole ini memiliki diameter rata-rata 1.1 meter (terkecil 0.4 meter dan terbesar 2.5 meter). Kemudian sink hole kedua merupakan jenis drop out sink hole, ditemukan sebanyak 8 titik dan berada di badan trase jalan, beberapa sink hole telah dilakukan penimbunan oleh kontraktor. Sink hole ini memiliki diameter rata-rata 0.9 meter (terkecil 0.5 meter dan terbesar 1.5 meter). Dari pengambilan data lapangan, didapatkan bahwa litologi batuan di sekitar area pembangunan jalan baru merupakan batuan karbonat yaitu batugamping dengan jenisnya yaitu packestone, wackestone, dan batugamping kristalin (Gambar 4). Packestone memiliki karakteristik warna batuan putih kekuningan, ukuran butir lempung-pasir sedang, grain supported, struktur sedimen masif. Komposisi material karbonat berukuran lempung-lanau (30\%) untuk matriks nya dan pasir halus-sedang $(60 \%)$ dan kalsit (10\%) untuk fragmennya. Wackestone memiliki karakteristik warna batuan putih kekuningan, ukuran butir lempung-pasir halus, mud supported, struktur sedimen masif. Komposisi material karbonat berukuran lempung-lanau (90\%) untuk matriks nya dan pasir halus $(8 \%)$ dan kalsit (2\%) untuk fragmennya. Batugamping kristalin memiliki karakteristik warna batuan putih bening, ukuran butir lanau-pasir kasar, struktur sedimen masif, merupakan batuan kristalin dengan material utama mineral kalsit hasil leaching dari batuan karbonat. Komposisi material karbonat berukuran lempung-lanau (30\%) dan kalsit (70\%). Batuan karbonat seperti 3 jenis batuan yang ditemukan di lokasi pembangunan jalan merupakan salah satu penyebab terbentuknya sink hole. Batuan karbonat merupakan batuan yang memiliki kandungan mineral karbonat lebih dari 50\%, walaupun rata-rata kandungannya diatas $90 \%$. Dua material utama penyusun batuan tersebut adalah kalsit $\left(\mathrm{CaCO}_{3}\right)$ dan dolomit $\left(\mathrm{MgCa}\left(\mathrm{CO}_{3}\right)_{2}\right.$. Secara mekanikal, batuan karbonat yang dapat membentuk sink hole memiliki karakteristik kuat tekan unconfined compressive strengths (UCS) sebesar 30-100 MPa (sebagian besar sink hole terbentuk di batuan dengan UCS < $60 \mathrm{MPa}$ ), berat jenis $2.6 \mathrm{kN} / \mathrm{m}^{3}$, dan nilai porositas $<2 \%$ (Waltham dkk, 2005).

Batuan karbonat merupakan batuan yang dapat mengalami pelarutan oleh air dengan mudah, pelarutan dalam batuan dipengaruhi oleh solubilitas (Kemampuan suatu zat kimia tertentu, zat terlarut/solute, untuk larut dalam suatu pelarut/solvent) dan nilai konstan pelarutan tertentu dari sebuah mineral (Waltham dkk, 2005).

\section{Interpretasi Geomorfologi}

Dalam kasus paket pembangunan jalan baru Jerukwudel-Baran-Duwet ini, penulis akan membahas morfologi daerah berdasarkan bentuk lahannya. Pada lokasi tersebut banyak ditemukan bentukan lahan doline dan cone karst/menara karst. Doline merupakan cekungan tertutup berbentuk bulat atau lonjong degan ukuran beberapa meter hingga lebih kurang satu kilometer (Ford dan Williams, 1992), sehingga Sweeting (1972) mengkategorikan doline dalam bentuklahan karst berskala sedang. Cone karst/Turmkarst/menara karst/pinacle karst merupakan tipe karst kedua yang sering dijumpai di daerah tropis. Tipe karst ini dicirikan oleh bukit-bukit dengan lereng terjal, biasanya ditemukan dalam kelompok yang dipisahkan satu sama lain dengan sungai atau dataran aluvial. Cone karst dibentuk berkembang apabila pelarutan lateral oleh muka air tanah yang sangat dangkal atau oleh sungai alogenik yang melewati singkapan batugamping (Sweeting, 1972). Dari hasil interpretasi penentuan bentukan doline dan cone karst di area paket pembangunan jalan baru Jerukwudel-Baran-Duwet (Gambar 5), terlihat bahwa tipe sink hole di kedua bentuk lahan tersebut berbeda, dimana pada bentukan doline ditemukan sink hole dengan jenis dropout sink hole dan pada bentukan cone karst ditemukan sink hole dengan jenis collapse sink hole. Hal tersebut dikarenakan genesa pembentukan kedua jenis sink hole tersebut yang berkaitan erat dengan litologi di bentuk lahan yang berbeda, dimana bentuk lahan doline akan memiliki litologi berupa endapan soil atau sedimen halus diatas batuan bedrock (karbonat), sedangkan bentuk lahan cone karst akan memiliki litologi berupa batuan karbonat sebagai bedrock yang tersingkap ke permukaan (baik karena proses tektonik maupun pembukaan lahan untuk pembuatan paket jalan). Sehingga pada area lembah doline banyak ditemukan amblesan tanah (dropout sink hole) yang berada di tengah badan jalan 
Identifikasi.., Aloysius Andrianto Saputro ${ }^{(1)}$, Christanto Yudha Saputra Sukamta ${ }^{(2)}$, Herlina Sulistyani ${ }^{(3)}$

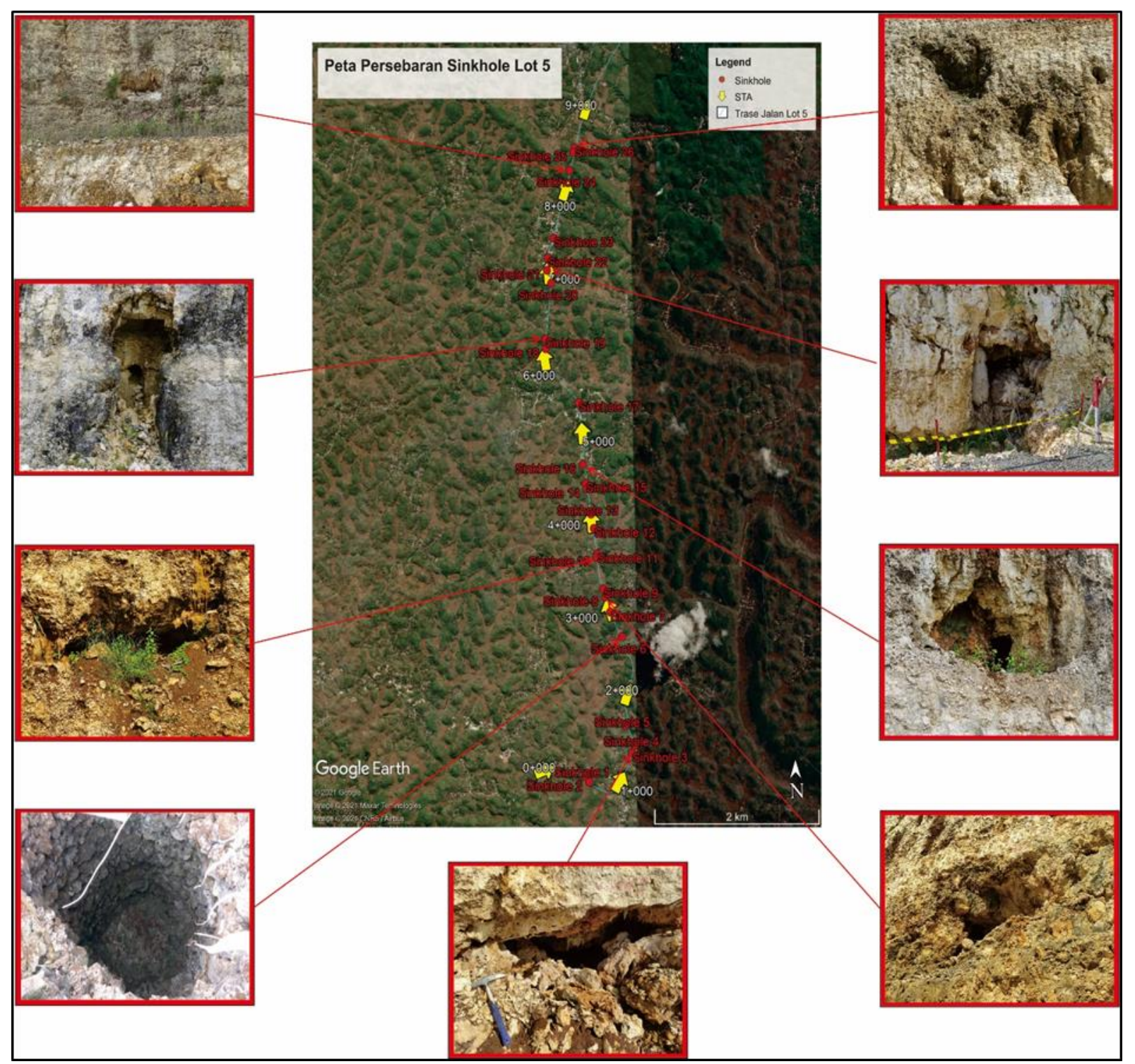

Gambar 3. Peta persebaran sink hole di wilayah pembangunan jalan baru Jerukwudel-Baran-Duwet

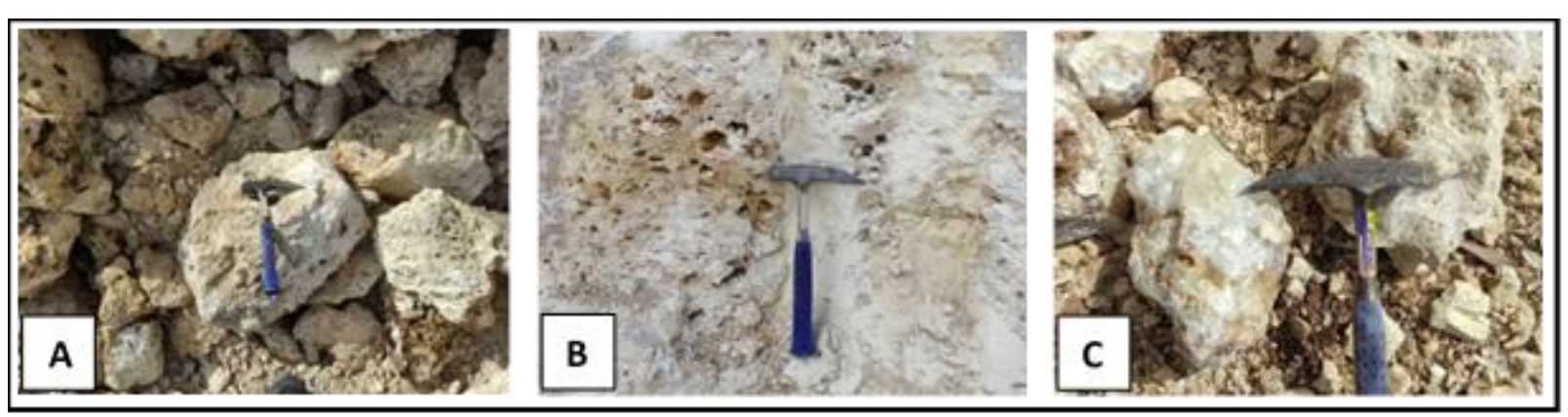

Gambar 4. Litologi di wilayah persebran sink hole pembangunan jalan baru Jerukwudel-Baran-Duwet (A: Packestone; B: Wackesone; C: Batugamping kristalin) 
sedangkan pada area tebing-tebing hasil penggalian bukit untuk pembuatan jalan, akan ditemukan longsoran berupa collapse sink hole yang dahulunya sebenarnya merupakan gua/rongga batuan karbonat yang belum tersingkap ke permukaan (namun karena adanya penggalian untuk pembukaan jalan, lubang tersebut muncul di tebing-tebing tepi jalan, yang berpotensi menghasilkan collapse sink hole).

\section{Interpretasi Data Geofisika}

Dari hasil pengukuran data Geolistrik yang dilakukan oleh tim survey awal PPK 1.2 Provinsi DIY, dapat dilihat jenis litologi maupun keberadaan rongga bawah permukaan, yaitu dilihat dari nilai ketahanan jenis/resistivity batuan. Resistivty/arus listrik pada batuan terjadi terutama akibat adanya fluida elektrolit pada pori-pori atau rekahan batuan. Nilai resistivitas batugamping terbilang cukup tinggi dibandingkan dengan batuan lainnya (Kecuali batuan beku, karena di lokasi paket secara geologi tidak/jarang sekali ditemukan batuan beku). Kemudian untuk soil atau lapisan sedimen yang biasa terbentuk diatas batugamping, memiliki nilai resistivitas yang cukup rendah, begitu juga dengan nilai resistivitas air yang sangat rendah (Palacky $\mathrm{GV}, 1987)$. Lapisan soil atau sedimen sendiri dapat hadir dalam bentuk materi pengisi rongga batuan, hal tersebut dapat diidentifikasikan dengan bentuk nilai resistivitas soil/sedimen yang tidak berlapis/layering secara horizontal diatas batuan bedrock (batugamping). Bentukan tersebut dapat berupa cekungan ataupun mengisi rongga yang ada diantara batugamping disekitarnya. Sedangkan untuk rongga dalam batuan sendiri cenderung akan memiliki nilai resistivitas yang sangat tinggi (dikarenakan merupakan ruang/pori kosong yang tidak memiliki kandungan material apapun), kenampakannya sendiri akan berupa anomali dalam keseluruhan batuan dan biasanya nilai resistivitasnya lebih tinggi dibandingkan batugamping disekitarnya. Dari interpretasi 5 lintasan geolistrik (Gambar 6), dapat diketahui bahwa data geolistrik dapat dipergunakan untuk melihat rongga/gua bawah permukaan yang memang banyak dijumpai di daerah karst seperti Gunung Kidul. Rongga bawah permukaan sendiri memiliki ciri-ciri nilai resistivitas yang sangat tinggi $(5000-25000 \mathrm{ohm} / \mathrm{m})$ serta memiliki bentuk yang khas/anomali diantara nilai resistivitas batugamping. Yaitu munculnya nilai resistivitas yang tiba-tiba tinggi diantara nilai resistivitas batugamping dan membentuk pola lingkaran/oval sepertu bentuk gua bawah permukaan. Rongga bawah tanah tersebut ditemukan di lintasan 1,3,6 \&
7, dan terletak tidak jauh dari permukaan (10-40 meter dibawah permukaan tanah) dan memiliki diameter dan panjang yang bervariasi (2-20 meter), hal tersebut menyebabkan potensi longsoran jalan akibat rongga bawah permukaan tersebut dapat terjadi di masa yang akan datang (karena proses pelarutan batuan yang masih terus terjadi dapat menyebabkan rongga bertambah besar), terutama pada lintasan 1 dimana jarak rongga hanya 5-10 meter dari permukaan badan jalan

Kemudian dari interpretasi geolistrik tersebut dapat ditentukan juga amblesan tanah/sink hole yang sudah terbentuk di permukaan tanah. Sink hole tersebut memiliki ciri-ciri berupa material soil/sedimen yang mengisi rongga/cekungan batuan karbonat, terlihat dari nilai resistivitas rendah (berwarna biru) yang mengisi diantara cekungan/rongga batuan resistivitas sedang-tinggi (hijau-merah). Hal tersebut terbentuk karena adanya pelarutan batugamping yang membentuk cekungan/rongga di permukaan yang kemudian terisi oleh material tanah hasil pelapukan batuan ataupun hasil transportasi dari sumber pelapukan di tempat lain. Hal ini menyebabkan potensi terjadinya amblesan tanah dikarenakan material pengisi tersebut berpotensi hilang/mengalami depresi karena sifatnya yang masih lemah dan tidak terkonsolidasi menjadi material keras/masif. Pada lintasan geolistrik sendiri, sink hole ini ditemukan pada lintasan $1,3,4$, \& 5 dengan dimater yang bervariasi (5-20 meter) dan berada di permukaan. Untuk sink hole di lintasan 4 sendiri memang sudah ditemukan di permukaan dan telah dilakukan penimbunan oleh pihak kontraktor jalan, tepatnya di STA $2+650$. 
Identifikasi.., Aloysius Andrianto Saputro ${ }^{(1)}$, Christanto Yudha Saputra Sukamta ${ }^{(2)}$, Herlina Sulistyani ${ }^{(3)}$
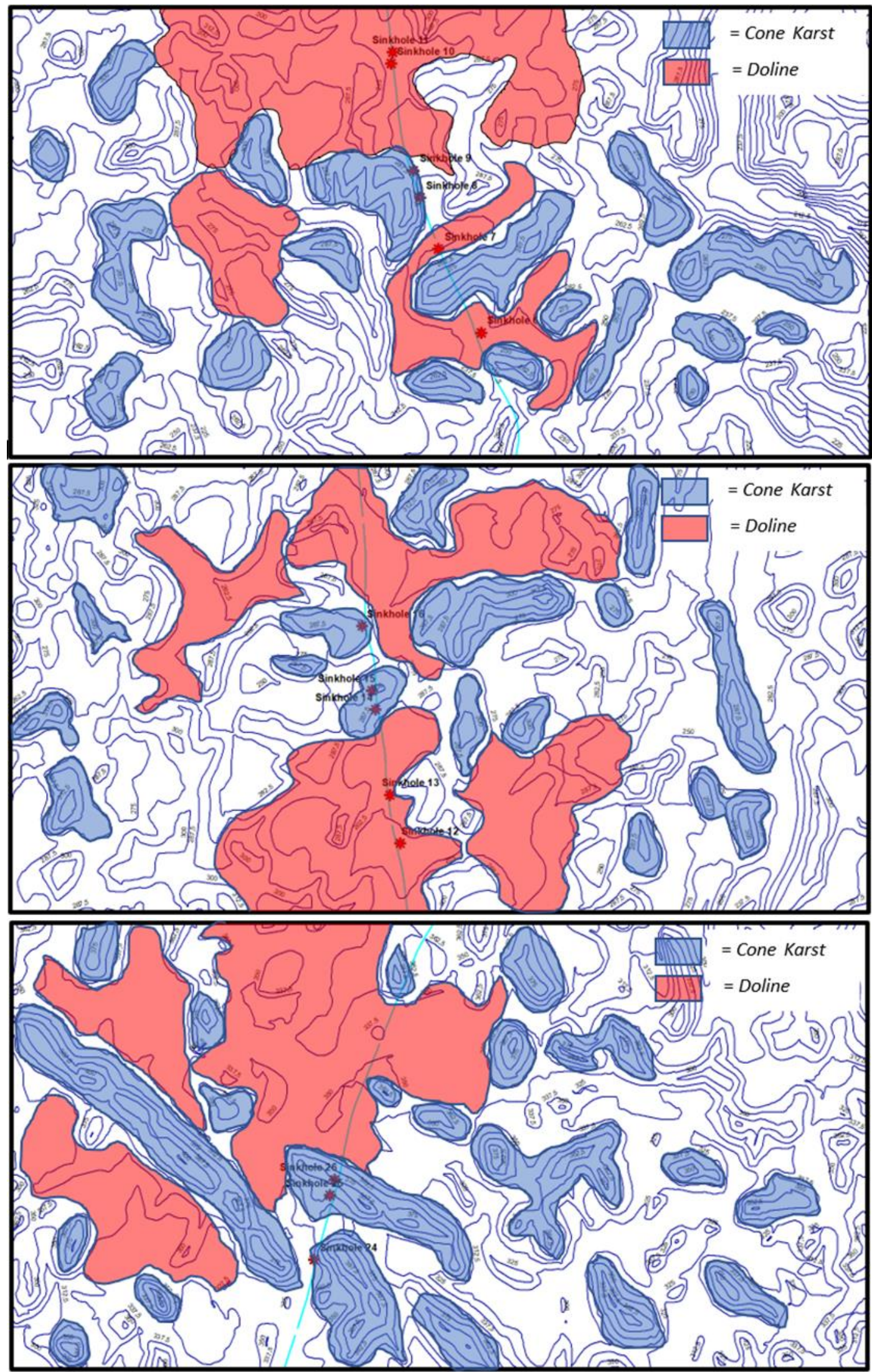

Gambar 5. Bentukan kontur doline dan cone karst di area paket pembangunan Jalan Baru Jerukwudel-BaranDuwet yang berasosiasi dengan persebaran collapse sink hole (Sink hole 8, 9, 14, 15, 16, 24, 25, dan 26) dan dropout sink hole (Sink hole 6, 7, 10, 11. 12, dan 13) dalam bentukan tersebut. 
Identifikasi.., Aloysius Andrianto Saputro ${ }^{(1)}$, Christanto Yudha Saputra Sukamta ${ }^{(2)}$, Herlina Sulistyani ${ }^{(3)}$
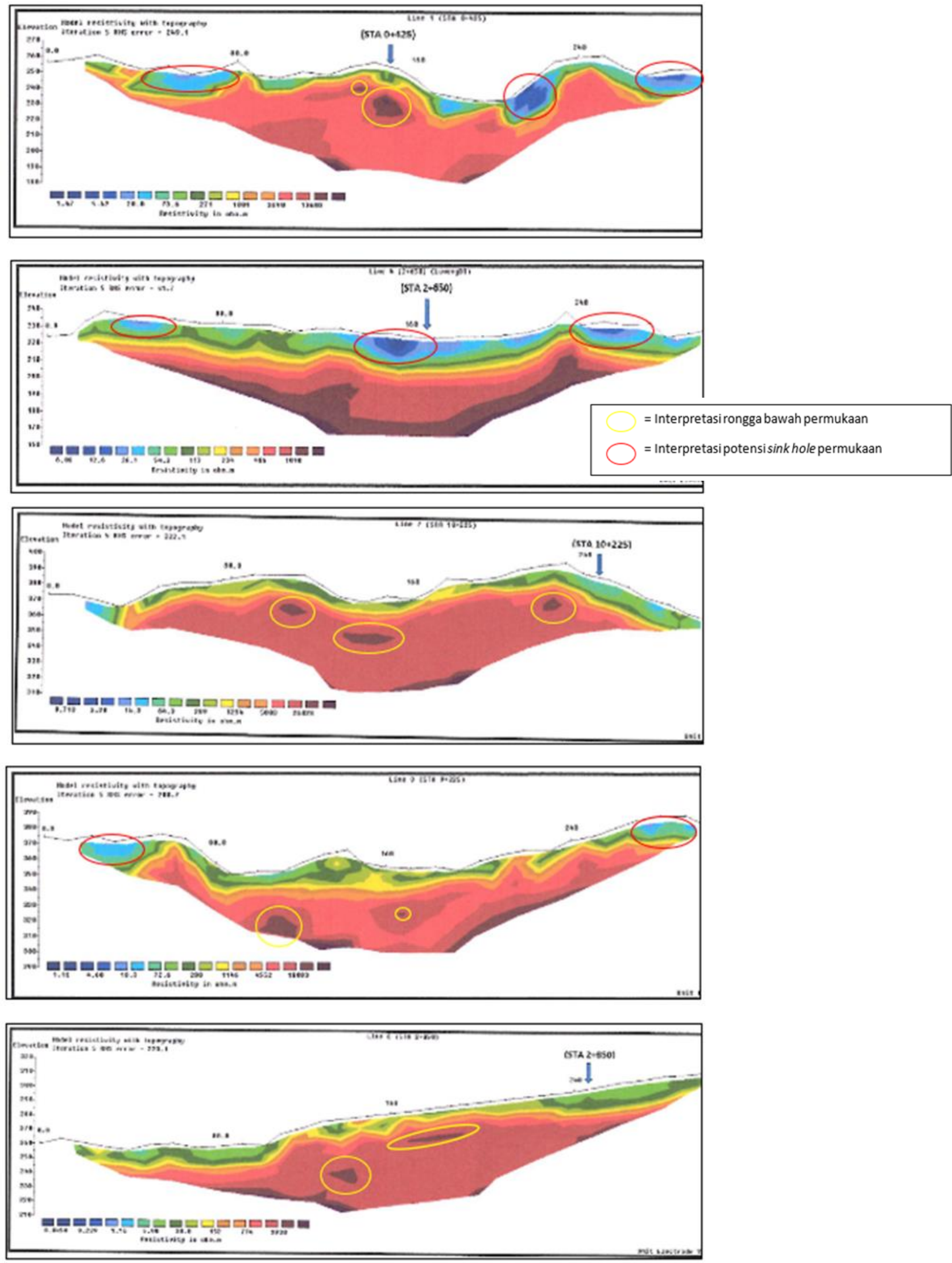

Gambar 6. Interpretasi rongga bawah permukaan \& sink hole dari data lintasan geolistrik Pembangunan Jalan Baru Jerukwudel-Baran-Duwet 


\section{PENUTUP}

\section{Kesimpulan}

1. Di area paket pembangunan jalan baru Jerukwudel-Baran-Duwet, terdapat 26 sink hole, dimana 18 buah merupakan jenis collapse sink hole (potensi longsoran batuan) dan 8 buah merupakan jenis dropout sink hole (potensi amblesan tanah). Kedua jenis sink hole tersebut berada di area dengan litologi batuan karbonat yang memicu pembentukan sink hole.

2. Terdapat dua jenis morfologi di area paket pembangunan jalan baru Jerukwudel-BaranDuwet yang berasosiasi dengan jenis sink hole yang terbentuk. Yaitu cone karts yang akan menghasilkan collapse sink hole dan lembah doline yang akan menghasilkan dropout sink hole.

3. Dari data geofisika yang ada, di area paket pembangunan jalan baru Jerukwudel-BaranDuwet, terdapat beberapa potensi rongga bawah permukaan dan sink hole permukaan.

\section{Saran}

1. Rekomendasi preventif untuk mencegah potensi sink hole muncul dalam rencana pembangunan jalan yaitu dengan cara melakukan studi pustaka dan penelitan pendahulu, survey awal, dan beberapa uji awal lapangan (geofisika dan pemboran misalnya) di area rencana pembangunan jalan. Sehingga hasil rekomendasi tersebut dapat dipakai Tim perencana pembangunan jalan sebagai dasar pembuatan trase jalan baru.

2. Mitigasi dropout sink hole dilakukan dengan cara menimbun dan menutup lubang terjadinya sink hole, serta melakukan perkuatan di area sekitar lubang. Untuk material penutup lubang sendiri dapat menggunakan material batuan ataupun sedimen yang tidak mudah larut oleh air. Mitigasi collapse sink hole dapat dilakukan dengan cara penguatan dinding tebing maupun pemantauan secara rutin kondisi dinding tebing.

\section{DAFTAR PUSTAKA}

Allen, A.S., (1984). Types of Land Subsidence, in: Poland, J.F., (ed.), Guidebook to Studies of Land Subsidence due to Groundwater Withdrawal, Studies and Report in Hydrology. UNESCO

CV. Mitra Karya Putera. (2019). Laporan Survey Tahanan Jenis 2D Paket Lot 5 Pembangunan Jalan Baru JerukwudelBaran-Duwet Provinsi DIY. Yogyakarta

Hugget, R.J., (2007). Fundamentals Of Geomorphology, Third Edition, Routledge Taylor \& Francis Group. London

Surono, Toha.B., \& Sudarno, (1992). Peta Geologi Lembar Surakarta-Giritontro, Pusat Penelitian dan Pengembangan Geologi, Bandung.

Sweeting, M.M., (1972), Karst Landforms, Macmillan, London.

Waltham T., Bell F., \& Culshaw, M., (2005). Sink holes and Subsidence: Karst and Cavernous Rocks in Engineering and Construction, Paris Publishing, Chichester, UK.

Widyaningtyas, C.P., Putra, D.P.E., (2014), Pemetaan Bahaya Amblesan di Daerah Karst Kecamatan Semanu, Kabupaten Gunung Kidul, Propinsi Daerah Istimewa, Prosiding Seminar Nasional Kebumian Ke-7, Yogyakarta 